\title{
The Paradoxes of the Journalistic Profession
}

\author{
An Historical Perspective
}

\author{
Svennik Høyer \& Epp Lauk
}

\section{The Search for \\ a New Collective Identity}

Until mid $19^{\text {th }}$ century the literary system was rather undifferentiated in many European countries. Authors of fiction and 'men of letters' in general served the same printers. It was sometimes difficult to distinguish between the kind of contributions that were printed in newspapers and those printed in other publications: book, journals etc. ${ }^{1}$ In the last decades of the $19^{\text {th }}$ century, however, publishing in general was in transition from loose and informal arrangements to a more formalised work organisation. In many countries the press became a regular newspaper industry addressed to a mass market with the help of the new and fabulously efficient technology of printing. Sharply falling prices for newsprint opened the market for many new competitors and started a boom in circulation from which all seemed to benefit, new and old newspapers alike. Other traits of the period were increased advertising and a fierce competition. ${ }^{2}$ An emerging new journalism focused on a variety of news for a heterogeneous audience, and more regular work routines for newspapermen, news-workers, journalists - or whatever was the favourite term for an aspiring profession. This was a new breed of writers for the $20^{\text {th }}$ century, quite different from the gentleman publicist and literate of most of the $19^{\text {th }}$ century.

When reporters moved from the street, bars and coffeehouses into more sheltered offices inside newspaper palaces in the metropolis of the modern world, and when journalism became a full-time job

Department of Media and Communication, University of Oslo, Boks 1093, Blindern, N-0317 Oslo, svennik.hoyer@media.uio.no

Department of Journalism, University of Tartu, Ülikooli 18,EE-50410Tartu,epp_l@ut.ee of some magnitude, the qualifications in demand also changed. Editors and journalists did not regularly belong to the educated upper class any more. The inevitable question became: Who shall be considered a journalist?

Some sort of trade-organisation could most effectively answer this question. Journalists started to organise like most other trades in the late $19^{\text {th }}$ century. Associations appeared both on the local, the national and international level: in Germany in the 1860s-1870s, in Scandinavia in $1880 \mathrm{~s}-1890 \mathrm{~s}$, and in the Baltic countries in the 1900s-1920s.

Great Britain saw the formation of its pioneering Newspaper Society in 1836. A National Association of Journalists with professional aims came in 1884 and founded the Institute of Journalists in 1890. A trade union - the National Union of Journalists - emerged only in 1907. Associations in the United States did not cover both editors, journalists and to some extent also publishers like the early European associations. ${ }^{3}$ The American Newspaper Publisher Association came into being in 1887 . Newsworkers began to organise in the 1890's and finally founded The Newspaper Guild in 1933, which eventually became an effective organisation for wage negotiations. ${ }^{4}$

On both continents it took a long time before journalists were involved in wage negotiations; loyalty to their newspaper, or an outright animosity from publishers, was for a long while apparently stronger than any urge to ally with fellow reporters. Only in the 1920s did codes of ethics begin to appear. ${ }^{5}$ But the first centres for the systematic study of journalism came a decade earlier: In the United States a School of Journalism was founded at the University of Missouri in 1908 and at Columbia University in 1912. ${ }^{6}$ The first institute and chair of 'Zeitungskunde' in European universities was established at the University of Leipzig in 1916 with 
Karl Bücher as head and professor. ${ }^{7}$ Regular studies in journalism outside Germany were started nine years later in Finland with a two-year course in journalism at the college level in $1925 .{ }^{8}$ For the rest of Europe regular trade schools and university studies were added only after World War II.

The first stated goals of the journalists' organisations were to define journalism as an occupation, to discuss among journalists themselves problems with the authorities, to invite delegates from journalist organisations in other countries to their conferences and to represent the national associations internationally. As Ulf Jonas Björk found in his review of the history of the International Union of Press Associations (ICP) between the 1890's and World War I, the delegates had a rather ambitious view of what might become the professional status of journalists, stressing education, the importance of professional associations and a code of professional ethics. ${ }^{9}$ However, this international concord was disrupted first by World War I and later by totalitarian regimes in the Soviet Empire and in Nazi Germany.

Great Britain has perhaps the longest unbroken tradition of journalism as a regular occupation. Consequently the accepted view of journalists varied a lot from hack writers, hired hands serving any cause for a living in the $17^{\text {th }}$ and $18^{\text {th }}$ centuries, ${ }^{10}$ to essayists of great integrity with considerable influence in their time, and to the press lords and entrepreneurs in public taste, appearing as the press was industrialised from the $1850 \mathrm{~s}$ forth. ${ }^{11}$

The expanding market for advertising has been described as rescuing the British press from the Old Corruption of the aristocracy, and the US press from the patronage of the political elite, the socalled dark age of the party press. Some thought that the increased advertising and commercialisation were corner stones of independence, whereas others maintained strongly that industrialisation was incompatible with professionalism. ${ }^{12}$ Mid-Victorian journalists in London were characterised as "Men of great ability and high character [who] gave their best to what they conceived to be a public service seeking recognition or reward beyond a very moderate emolument for their labour." 13 From this vantage point the image of journalism at the turn of the $19^{\text {th }}$ century had to be rather pessimistic, as expressed by an editor in the Evening News to a departing colleague: "You left journalism a profession, we have made it a branch of commerce."

\section{White-Collar Workers or Professionals?}

At the turn of the $19^{\text {th }}$ century the cost of new technology and distribution had increased to a level were only wealthy businessmen could own newspapers in the larger cities. ${ }^{14}$ In 1871 Horace Greeley claimed that the production of an issue of his Tribune needed between four and five hundred persons at the cost of approximately $\$ 20.000 .{ }^{15}$

The larger work organisation brought a clearer hierarchy into newspaper firms. So another latent question at the time was: To what part of society did the new journalists belong? Some early efforts were made to define journalists as belonging to a "fourth estate" forming - just like intellectuals - a group of opinion-makers above social classes and interests. ${ }^{16}$

A contrast emerged between the objective description of journalism and the subjective image, which journalists held of their work. Journalists endured long hours in news-factories combined with low wages and a lack of job security, and were exploited by publishers bent on earning money some of which - like Pulitzer, Hearst, Northcliffe, Beaverbrook and others - were incredibly rich. All of this might have bound journalists in common solidarity to typographers and office workers. But journalists rarely thought that low wages made them into 'workers'. Being responsible for the content and the public image of newspapers, working close to members of the elites in reporting, journalists were also closer to public responses than other groups in the newspaper industry. They are urgently in need of a strong moral position. Journalists rather early therefore identified with other wellto-do professions like teachers, lawyers, physicians etc. And it was some psychological reasons for this imaginary 'upward mobility'.

Until the last decades of the $19^{\text {th }}$ century newspapers employed few if any journalists, and only some few editors full time. For contributions the printers depended on correspondents and a milieu of freelancing writers, which belonged to the intellectual upper class. For instance, during the first five decades of the $19^{\text {th }}$ century half of the 114 Finnish editors were university teachers or schoolmasters. ${ }^{17}$ Among 38 fully employed journalists in Germany between 1800-1848 27 had worked as lawyers, officers, teachers, diplomats etc. before becoming journalists. All had academic degrees and among the 25 half-time employed: five were professors, four 
rectors, three clergymen, three lawyers etc. ${ }^{18}$ In England editors in the 1870s-1880s were hired from "Oxbridge" or similar university studies, even to the regional press. Often they were paid as other professionals. Editors tried to maintain a good reputation for their newspapers in higher society and cared less for the daily business of news making, ${ }^{19}$ this was the job of the much lower paid journalists and sub-editors, who lived in almost separate quarters within the newspaper.

This system, of course, caused disdain among the poorly paid journalists, both towards the editors and towards the value of their higher education. ${ }^{20}$ But even editors were easily sacked when active publishers became dissatisfied with how editors interpreted their intentions. Alfred Harmsworth had all kinds of original ideas, peculiar ideas by current Fleet Street standards in 1896, about his new creation - the Daily Mail. It was easy to get a job as the Mail prospered but hard to keep it. "The Mail will suck out your brain, then sack you." was the watchword at street level, S. J. Taylor writes. ${ }^{21}$

Consequently, the old profile of 'haute bourgeoisie' in journalism did not apply so well as a comprehensive characteristic at the beginning of the $19^{\text {th }}$ century for which Arthur J. Kaul calls American journalists 'proletarian professionals'. Professionalism hides latent class conflicts in the press, he claims. ${ }^{22}$ Curtis Smythe graphically describes the meagre working conditions reporters between 1880 and 1900. Journalists worked more and were less paid than plumbers, and not much more than compositors; and they were paid for volume of work in terms of column inches or lines printed, not for quality; they were hired and fired at will by publishers. ${ }^{23}$ Without strong trade unions, journalists eventually became unable to defend routine journalism from being de-skilled through industrialisation and the ensuing bureaucratisation of editorial procedures at the end of the $19^{\text {th }}$ century. ${ }^{24}$

Mary Cronin and Hanno Hardt et. al. agree and further maintain that it was the publishers, not the journalists in the US, who most eagerly defined journalism as a profession with an obligation to produce neutral and informative news. Publishers did this on two grounds: first, by binding journalism to established facts and opinions, and thus defusing any radical potentialities that social analysis could harbour, and, second, by infusing journalists with a bourgeois ideal of professionalism. ${ }^{25}$ Or in Kaul's more pungent characterisation: "The professionalisation of journalism, with its "public service" ethos, was an "adaptation manoeuvre" to insulate newspaper owners/publishers against profit-threat- ening commercial crises, class conflicts, and public disenchantment with the press."

Michael Schudson by contrast, maintains that the professional ideology of journalists was a reflection of the general trend of most white-collar occupations to raise their status and role in society by copying certain traits from more traditional professions, emphasising first and foremost the ideal of 'objectivity'. ${ }^{26}$ This was one of several conscious efforts to place journalism above social stratification.

In some respects journalism had some typical similarities with middle class professions. In other respects some journalists were threatened with proleterianisation. These two trends were not necessarily inconsistent psychologically as long as journalists regarded their work as a sort of calling, but contradictory images may have added some ambivalence in establishing journalism as a neutralised profession.

\section{Roles and Texts}

As the amount of information about newspapers grew from the 1880 s the US Journalists "worked with a social institution grown so complex by 1890 that even they had difficulty understanding it" remarks Dicken-Garcia. ${ }^{27}$ But the appearance of a specific journalistic text in this period was also a sign of emerging professionalism as Michael Schudson maintains. The journalistic interview coming into vogue in the $1870 \mathrm{~s}-1880 \mathrm{~s}^{28}$ signalled a silent revolution in American journalism. ${ }^{29}$ In Great Britain the news interview was introduced in $1889 .{ }^{30}$ By the 1860 s-1870s new technology made it possible to aerate the text and make it easier to read by typographical means. Stories were demarcated, expanded and were given more informative headlines, with more illustrations, shorter paragraphs etc. ${ }^{31}$ The news wires made it possible for newspapers to introduce a 24 hour news cycle.

These methods gave journalists the initiative in deciding what was important, seeking their desired information where it was available and most relevant. With the prestige of their media organisation and on the behalf of the public's right to know journalists could ask anyone for information without being obliged to respond to the answers given by the interviewee. The underlying threat being that the interviewer ultimately took control of what should be published. The interviewee in turn spoke to an audience, not to the journalist. This questioning technique put the sources of information on the defensive implying new kinds interactions that re- 
quired bargaining strength on the part of journalists, which they took from a growing newspaper industry. H. G. Wells complained already in 1894 of the 'interviewing ordeal'. ${ }^{32}$ Others looked at the interview with contempt and as an illicit method of invading privacy.

From the 1850 s the electric telegraph had a direct impact on journalism. News wires diminished the time elapsed before events could be reported. Jürgen Wilke finds e.g. that between 1856 and 1906 reported events which had occurred in the last 24hours, increased from 11 percent to 95 percent in the German press. ${ }^{33}$ News wires also diminished the scope of reported events. Spot news emphasised single actors, specific locations and timing within a series of similar events.

As story time shrank the truncated story line was compensated for by more superficial news values of sensationalism. The understanding of each story further depended on readers hooked on the stream of news consciousness, learning the genres of presentation. Chronology became less important in the composition of each article and the meaning of the latest news telegram rested on news stories that were told earlier.

As the press fell away from literature, fictions in turn broaden its appeal by making the location less specific and the story less time-bound. ${ }^{34}$ At the same time as 'objectivity' became the accepted method of news reporting; the presence of journalists disappeared from the text. Opinions are those of experts and celebrities. News-interviews put the burden of proof on the information sources, and in the same process relieved reporters from the obligation to have an opinion on, or being responsible for, the documentation of the subject matter. Standard formulas of presentation, like the inverted pyramid, utilised the idea of 'balance' and 'objectivity' to a degree where also the active reader is left out. The reader cannot identify the sender by who is responsible for the story but must accept the report as 'reality' without interpreters or disseminators. $\mathrm{S} / \mathrm{he}$ is thus relegated to an observer of the discourse between chosen experts and the imaginary journalist. ${ }^{35}$ The changing methods and formats of reporting and presentation thus combined to redefine the role of journalists.

\section{Commitments \\ and Objectivity in the US}

Textual genres in journalism not only define social roles they also influences the transactions between journalists and members of the elite as in the case of the news interview. Among elites the politicians are most often among the most important one for journalists. Conflicting ideas of who is entitled to speak for the public pursues political journalism like a shadow. To be above politics and not an instrument of politicians is a token both of influence and of professional integrity. This simple rule, as we see it today, was not always realised.

In his prospectus for New York Herald James Gordon Bennett, assured prospective readers in 1835 that his newspaper would "openly disclaim ... all party-all politics." ${ }^{36}$ This was an early presage of the doctrine of journalistic 'objectivity'. Hazel Dicken-Garzia finds in her survey of critical studies of the press in American newspapers by the middle of the $19^{\text {th }}$ century that “ . ... neither the British nor Americans had confronted forthrightly whether journalism should, or could, be totally separated form partisanism ... only after [the middle of the $19^{\text {th }}$ century] ... did writers begin to deal with the issue in depth" ${ }^{37}$ But the 'depolitisation' of the American press seems to be a more gradual and outdrawn process than expected. Only after World War I did e.g. a clear political bias disappear from the Detroit press during presidential election campaigns. $^{38}$

Julian Ralph, a New York Sun correspondent, described in 1903 the normal negotiation between journalists and important officials in the last two decades of the $19^{\text {th }}$ century as reaching an agreement "upon terms of equality ... to publish or not to publish, as the two agree". ${ }^{39}$ The power of journalists in such negotiations changed as newspapers grew in circulation and influence, but it was also countered by public relations coming into business from the turn of the $19^{\text {th }}$ century, as an answer to the muckraking journalism. Direct access to news sources were often filtered by publicity agents. In the 1920 s and 1930s it was estimated that press agents inspired 50 to 60 percent of news stories. ${ }^{40}$

John C. Nerone claims that the unity of commercialism and political independence formed an enduring premise for how American journalism addressed itself to the public. ${ }^{41}$ The populism of the penny press, "speaking the public voice", was superseded by the sensationalism and commercialism of the yellow press, addressing itself to the growing and prosperous middle class.

\section{Some Cross-Cultural Examples}

If the idea of journalistic objectivity was not a given doctrine, but emerged slowly over several decades in the US it is only to be expected that 'objectivity' 
may have different connotations in other cultural contexts. George Boyce describes how the British press related to politics in early $20^{\text {th }}$ century as follows: "... the press was an extension of the political system, not a check or balance to Parliament and Executive, but inextricably mixed up with these institutions. Government was not 'government by journalism' ... but government by politicians, with journalists acting as go-betweens, advisers, and, occasionally, opponents of practicing politicians." 42

After centuries of censorship and enforced silence on domestic public affairs, the right to deviate from the views of governments was a sign of journalistic integrity on the continent of Europe. In Central and some Eastern European countries journalists outside the boulevard press typically had a three-forked career. Starting out as undistinguished intellectuals they worked as journalists to become either recognized politicians or literary writers. ${ }^{43}$ The situation was not very different in France, Germany or Scandinavia at the time. The party press often served as a job reservoir for politicians out of office.

In a comparison of French and Anglo-American journalism between the 1830 s and the 1930 s Jean K. Chalaby points to censorship as a decisive factor, which explains many differences of how journalism developed in the two countries. ${ }^{44}$ Censorship was more strict and lasted longer in France, which fostered more allegoric and implicit journalism than in Great Britain. ${ }^{45}$ Thus, censorship also "delayed" the diffusion of a modern news paradigm.

Against this background Chalaby looks at how news was evaluated in the two countries, with an emphasis on comments and a literary style in the French press as compared to the factual and neutral journalism in the Anglo-American press. He then outlines some consequences of such differences in the amount of informational news presented, in the variety of journalistic genres, in the volume of advertising, in the number of pages and of hired journalists etc. - more of this in the British press, less in the French. In France journalism was an intellectual calling within a more limited and highbrow readership, in England it became a regular occupation of a rather low social standing within a socially diffuse mass audience. Despite all these differences, the French press gradually adopted the American inspired news-journalism from the 1920s.

These analyses may be extended to Germany where the continental European tradition of opinion journalism was very strong: “ ... the opinionated editor and commentator was seen as the epitome of the journalistic profession", observe Wolfgang Donsbach and Bettina Klett. ${ }^{46}$
To make things more complicated, compared to the United States the Scandinavian press developed in opposite directions, both into a party press and a commercial press in the same period, but market expansion led in most cases to tighter relations between party and press. ${ }^{47}$ Newspapers economics gives us few clues to an explanation of the emerging party press. On the contrary, the opening up of a mass market for newspapers in Scandinavia lagged only a decade at most after the US and the downfall of its party press. The curves for newspaper consumption are almost parallel in form. In both Denmark and Norway the sharpest rise in newspaper consumption occurred between 1880 and 1900 just as in the US. ${ }^{48}$ In Estonia the same phenomenon appeared during the years of the Russian Revolution in 1905-1907.49

As new technologies and infrastructures promised mass circulation newspaper entrepreneurs entered the market in the 1860 s for profit, some apolitical, and some lightly liberal in tone. The first modern newspaper publisher was J. C. Ferslew in Copenhagen who operated in the 1860s, 1870s and 1880 s and started altogether four papers, both upand downmarket at the same time.

Ferslew had probably the greatest publishing empire in Scandinavia in the 1860s. The first of popular papers in Denmark started in 1860 as Folkets Dagblad (The Peoples Daily), which soon reached a wide circulation of 18000 in 1863 . In 1864 Ferslew started a competitor Dags-Telegrafen (The Daily Telegraph), which became the market leader around 1872-73. Nine years after his first newspaper Ferslew started Aftenposten (Evening Post) in the same market segment. Ferslew's strategy for the downmarket was to avoid opinionated articles in an abstract style. Instead, Ferslew's editors stressed an apolitical stand, concentrating on news or on interesting trivialities of life in the "Parisian" style of boulevard papers. This was partly meant to meet the upcoming socialist newspapers and their highly ideological agitation. Finally in 1876 Ferslew started Nationaltidende (The National Daily) with an aim not so much to gain a profit or to pronounce a social or political program as to gain prestige in the upmarket. ${ }^{50}$

Marion Marzolf describes how the American 'new journalism' of Joseph Pulitzer, James Gordon Bennett Jr., and Adolph Ochs in the 1870s and 1880s influenced Scandinavian editors. The most famous "innovator" was Henrik Cavling an ambitious young Danish reporter who travelled the world and made five trips to the US in the $1880 \mathrm{~s}$ and 1890s. He was much impressed by American 
journalism and when he became editor of one of the major Copenhagen dailies Politiken in 1905 he changed his newspaper instantly by giving priority to news at the front page and hiding editorials and comments inside on special pages. Influenced by Cavling's example the deputy editor Oscar Hemberg of Dagens Nyheter in Stockholm reshaped his paper after an American model. ${ }^{51}$

\section{Different Roads to Professionalism?}

Just as central ideas of professional integrity differ between cultures and political systems, the strategies pursued by professions in different national settings may also vary, due to the same cultural and political differences. The theories of professionalisation, by contrast, seem to exist outside history. They lack a relevant historical perspective cross-nationally for the $18^{\text {th }}$ and the $19^{\text {th }}$ centuries. The theories of professionalism also seem to be inadequate to describe important developments in the work situations of professionals towards the end of the $20^{\text {th }}$ century and in the beginning of the $21^{\text {st }}$. Present theories fail to take proper account of professional teamwork, which increasingly replaces the idea of an autonomous professional with group anchored responsibilities shared between different professions.

The characteristics of professional occupations were widely discussed by Anglo-American sociologists, especially in 1960s and 1970s. ${ }^{52}$ German and Scandinavian sociologists also adopted their terminology and basic ideas. ${ }^{53}$ Millerson gives a capsule definition of professional work as: a service provided with a variety of specialised skills on the bases of theoretical or scientific knowledge, given by the individual professional according to a given practice controlled by the professional organisation. ${ }^{54}$ The process of professionalisation is completed when organisations control recruitment to the specialist field and efficiently protect the scientific nature and the integrity of professional decisions. ${ }^{55}$ This 'ideal type' is abstracted from known characteristics of model professions like medicine and law. ${ }^{56}$ Implicit in such definitions are the idea that basic features of such professions can be found in various local contexts.

Leonore O'Boyle contends that the development of professions can be studied as "natural histories", likely to repeat itself when different countries modernise. ${ }^{57}$ This development may follow similar trajectories in many countries, but not necessarily synchronically. A typical sociological approach to the study of professionalism, in the "natural his- tory' school, starts from Harold L. Wilensky's influential article: "The Professionalization of Everyone?" Comparing the development of 18 professions in the United States, Wilensky defined five successive stages through which an occupation has to pass on its way towards professionalism. ${ }^{58}$

Professionalisation, however, cannot be depicted only as a linear or unbroken progress of events repeating itself from one country to another because the very idea of a separate journalistic profession is likely to be challenged differently from one political system to another. We argue that elements of professionalism will manifest itself during the history of various national media systems, but not necessarily as "natural histories". Even some routine transactions between politicians and journalists differ between Western democracies today. The hierarchically controlled and elite-centred access to public information in countries like Great Britain and France contrasts sharply with the Scandinavian countries and the US. For instance the Official Secrets Act in the UK, which virtually make all information from government confidential and prohibits Civil Servants to pass information to the press, versus the Freedom of Information Act in the US, and similar laws in Sweden, which demand the administration to be as open as possible to the public.

Taking a broader view Hannes Siegrist suggests that professionalisation contains several divergent processes "which occur within institutions of learning, the division of labour, the economic market, and areas of political and social powers" ${ }^{59}$ Such divergent contexts may account for the different trajectories which professionalisation followed in various countries. In the England and the US the professions developed out of guilds, membership and training controlled by the professional associations themselves in a market unrestrained by government regulations. ${ }^{60}$ In Continental Europe, by contrast, kings and governments initiated professionalism through a license system. Regulatory measures were established, relating to codes of ethical conduct, higher education, qualifying standards, limits on the number of members admitted to the professions and a scale of fees for certified professionals.

From the middle of the $18^{\text {th }}$ century these 'state professions' converged slowly towards the AngloSaxon model of more professional autonomy in the job market. It gained momentum during the $1870 \mathrm{~s}$ when the professionals themselves fought for a more open access to their professions. To meet a growing demand for professional service outside the public administration domain the professions escaped from their bondage to the Civil Service by es- 
tablishing themselves in an open market, thus becoming counterparts to governments in professional affairs. Professional organisations on their own defined the scope of practice, determined norms and values for its members, and struggled for a general recognition of their integrity from other social groups (Sigerist, op. cit.).

In summary then: If a uniform line of development from occupations to professions are accepted as a valid theory, it can hardly explain how professions developed cross-nationally, and it can not at all account for how journalism have developed some professional traits. Starting out in the opposite direction of Wilensky, we suggest that journalism is approaching a professional status by different routes. In the next two sections we will pursue this line of thought, taking a closer look at attitudes towards professionalism, first in different national settings and then in the organizational setting, which characterise professional work today.

\section{Common Values of Journalism?}

After a comprehensive survey of the literature on the character of journalistic work in 1990 Randal A. Beam found that journalists support most of the classical criteria of professionalism. ${ }^{61}$ Beam emphasises the willingness of journalists to stress education as a necessary preparation for their career. Similarly journalists appreciate participation in professional organisations, he or she has a committed and disinterested approach to topics covered in their journalism, as well as a commitment to accuracy, to the service of public interest, and to protect their access to information. Finally, there is the ambition to win occupational prizes. ${ }^{62}$ This is the selfimage of a typically professional journalist in the United States.

As we have seen, according to sociological theory the fully professionalised occupation shall by and large remain the same from one country to another. For journalists, however, recent research findings point in different directions when it comes to the existence of commonly held professional attitudes and values, cross-nationally.

Colin Sparks and Slavko Splichal in their study of journalism freshmen in 22 countries identified some core values held by most of their respondents. They conclude that by the attitudes to their coming profession there "is no typical 'European', 'West-European', 'American', 'Latin-American', 'socialist' or any other politically or geographically defined student of journalism." 63 College education seem to promote a trans-cultural professional canon and a unified role perception rather than separate images of the journalist.

In his concluding chapter of The Global Journal$i s t$, an international survey based on equivalent questionnaires, David H. Weaver contradicts Sparks and Splichal findings when it comes to the attitudes of working journalists. ${ }^{64}$ Analysing answers by the educational background of journalists and by their working conditions the main impression is a wide variety of attitudes towards professional values cross nationally. Compared nation by nation the answers demonstrate little or no international consensus about the purpose of journalism among seasoned journalists, except to bring the news as fast as possible to the audience. In their own view working journalists seem to be a slightly different species in different environments.

Core values and role models are emphasised differently within different political systems. Journalists from countries with old democratic traditions like Britain, the U.S., Australia, Finland, evaluate more highly the "watchdog role" of the media than journalists from the countries with short experience of democratic government. British journalists see their main task as being watchdogs of public interests, and supplying the public with information. German journalists stress interpretation of the news, while Finnish and Swedish journalists both want to actively examine public officials and explain complicated events to the audience. ${ }^{65}$ Renate Köcher found similar differences in attitudes towards sources of information and authorities. British journalists are more aggressive in their attitudes towards authorities than German journalists. ${ }^{66}$ Soviet journalists, by contrast, were not allowed to be unbiased. They were expected to promote the party cause actively. ${ }^{67}$

The best of times for journalists to be politically committed and yet to be professionally independent are during the rare transitions in a nations life when an old political system is vanishing and when new opportunities and values have to be explored. ${ }^{68}$ According to a survey in 1988 such collective experiences of transformation were reflected in the attitudes of Estonian journalists. Their most important goal, professionally, was to defend and express the interests of the people, in line with the "teacher role" promoted in Soviet time. In a more recent survey from 1995, though, journalists by and large had adopted a more 'western' role model of a neutral transmitter and of a "watchdog" philosophy. ${ }^{69}$

In the written codes of ethics, it is found, some values are widely accepted cross-nationally, in contrast to what was found when attitudes were meas- 
ured individually. In 1994-95 the Department of Journalism and Mass Communication at the University of Tampere collected codes of professional conduct from 31 European countries from the Atlantic to the Urals. ${ }^{70}$ Codes that are adopted by the journalist's associations. The most widely accepted responsibilities in these documents are the accountability of journalists towards the public and towards sources and referents. Among the values mentioned in at least half of the 31 national codes, the following list of six may be taken as a beginning of an European consensus, according to Nordenstreng: 1. truthfulness, 2. freedom of expression, 3. equality, or non-discrimination, 4. fairness, 5. respect for the integrity of sources, and 6. respect for the professional autonomy of journalism. Much in these codes of ethics are replicas of each other, but even though, they have all been locally negotiated and agreed upon.

So far empirical research points in different directions. Better methods may reveal an underlying or emerging consensus on professional values cross nationally. The overall impression from our overview, however, is that the self-perception and the professional values among journalists, change with the national and cultural contexts.

\section{Responsibility in the Organisational Context}

The attitudinal components of professionalism, portrayed above may and may not be supported within the institutional settings in which journalists operate. In their work journalists act in symbiosis with their media organisation, to some extent they must adapt to the overall conditions of their newspapers, radio- or television stations. In the United States attitudes on professional matters differ by the nature of the media organisation to which journalists belong. From their surveys of American journalists Weaver and Wilhoit concluded that the organisational environment, as opposed to the education and social background of journalists, was the strongest predictor of their role orientation. The strongest professional self-image among American journalists in the 1990s was that of a disseminator (getting the news to the public quickly), but also the watchdog ideology was strong. ${ }^{71}$

The idea of collective responsibilities does not fit well with the theories of professionalisation. In a strictly logical manner it is difficult to say that journalists lack responsibility for a corporate product. It may still be meaningful to say that professional standards are sometimes neglected in the edi- torial process. Ethical values are primarily linked to the media organisation, secondarily to journalists working in team.

More recent findings give the impression that the work situation for many journalists gives them little room for manoeuvre. ${ }^{72}$ As the sender organisation grows in size the balance of control over the media product is tipped in the direction of management: much more is planned according to given journalistic routines, formats and typographical profiles, which can be bureaucratically manipulated. However, information technology can upset an oldfashioned linear flow production. At the same time computers allow for more flexibility. Routines are changed as well as job delimitations towards a more decentralised production system.

Merja Helle, a former experienced journalist, has studied how new computer technology changed work routines in a Finnish newspaper. ${ }^{73}$ One of her conclusions was that: "Instead of the central editors, the five layout desks for different news departments became the critical points in the production flow." The focus of collegial discussions shifted towards the whole newspaper edition rather than the individual news story: "Fitting the news stories into the newshole left by the ads, keeping the deadlines, sending pages to the printing plants, choosing the main stories for the front page, editing stories and continuing them the next day ... " these were the jobs that could rotate across earlier professional borders and, as one particular consequence, removed the task of the former news evening editor. The new routines challenged honoured specialities and privileges: "Instead of closely guarded individual newsbeats, people had formed new follow-up groups that did not anymore follow the functions of bureaucracy. ... The new division of labor crossed the departmental boundaries and the reporters were writing for other departments also." (p. 107).

Helle's analysis of newsrooms above is a far cry from the model work situations in the theories of professionalism in which autonomous professionals usually are depicted to work alone and have a personal responsibility to his or her client. In Merja Helle's analysis the professional product loose its personal touch. Major news stories are not primarily written or personally authored they are as much planned, organised and presented in an organisational setting. A major news story is a collective product: from the ideas are accepted, then being researched and further observations collected by active field work, before reaching the final stage of composing the page or the whole newspaper edi- 
tion. After leaving their texts the personal responsibilities of reporters are fragmented in the editorial process.

The idea of the autonomous professional (gatekeeper) as an individual decision-maker has for many years been challenged in media studies. Rather the most accepted view now is of a media organisation as the most important unit of decisions. ${ }^{74}$ Within this framework, however, the leeway of individual decisions for journalists may vary greatly. ${ }^{75}$ To clarify the ambiguous position of journalists, it may help to distinguish between 'integrity', which is a personal quality with moral implications, and 'autonomy', which is a social status obtained by collective professional efforts. ${ }^{76}$

Our overall impression from the studies named above is that the accepted formula of individual autonomy as a criterion for professional performance has become void or at least insufficient as most professions have been enlisted in teamwork and entangled in bureaucracies.

The sociology of professions does not usually take account of how assignments are performed within complex projects. To take an example from the medical profession, chief physicians administering public health hospitals in Scandinavia must accept political decisions made outside their hospital, which have consequences for how they can organise medical treatment. Within the hospital they must balance demands from medical colleagues with expectations from other professional groups. In negotiations of working conditions and responsibilities doctors represent opposite roles and must make compromises between different sorts of professional logics. ${ }^{77}$ In response to such social pressures towards «de-professionalisation» in the last three decades the physicians internally tend to regroup into three clearly defined segments: the administrative and the scientific elites respectively, as compared to the rank and file doctors. ${ }^{78}$ In sum the doctors have lost much control and must increasingly share it with bureaucrats and other professions. ${ }^{79}$ Much of the same bureaucratisation coupled with a loss of control for the scientific staff have been observed in Scandinavian universities.

In this light, it may be argued that the situation portrayed for journalists is the rule rather than the exception today. Doctors in hospitals are as dependent on teamwork as journalists are in the media. These are dependencies, which define the substance of decisions and the professional's freedom to control professional decisions alone. Autonomy in complex decision-making processes is more than ever something, which must be defined and protected by professional organisations, rather than by individuals alone face to face with a client or a colleague.

\section{Epilogue}

The liberal professions are invariably conceived of as a corpus of specialised knowledge of a scientific kind acquired through a long personal training qualifying for a practice exercised under personal responsibility. The most typical response in social science writings on professionalism is to deny journalists any possible status as professionals. Journalists are employed in complex organisations where an efficient bureaucracy constitutes their immediate environment. From a sociological point of view journalism defies most attempts at precise definition; it remains a mysterious mixture of the personal and the public.

The idea of responsibilities, not to mention any professional privileges, for journalists disappears also in the context of jurisprudence. Media laws usually claim either the publisher or the editor to be responsible for the content of their media, not the journalist who wrote the objectionable story. The Supreme Court in the US gives the press, and even media conglomerates, protection under the First Amendment using the construction of a "corporate personhood', in fact putting the public responsibilities of media in the hands of owners. ${ }^{80}$

In a historical perspective the role of the liberal professions more generally seems to become more ambivalent. In developed economies we see three apparently contradictory trends: one of expanding professionalisation among occupations, another of increased domination in most industries by some few big companies - operated by professionals - and finally the government taking over responsibility of a large amount of the service sector - where we find most of the professionals. ${ }^{81}$ As the number of professions multiplies, the typical place of work for professionals becomes the complex organisation: large corporations and large public institutions. Both doctors, lawyers, professors and engineers increasingly work in complex, hierarchical and bureaucratised environments in hospitals, universities, law firms, engineering and electronic companies - just to mention a few. The project-oriented and the interdisciplinary problem-solving team have to a large extent replaced the individual consultant. This mixture of various elements of professionalism within a chain of task-oriented decisions sometimes blur the limits of the professional competencies involved and makes personal responsibilities more diffuse. 
The kind of professionalism performed by modern media depends to a great extent upon how it is organised: it relies on the kind of competencies which is build into it, it depends on how talents are combined, on how information and ideas are transformed into journalistic products etc.

If we think of journalism as a uniform occupation this situation can lead to quite contradictory conclusions. The prestige of journalists tends to grow with the size of their media. But as media grow both in size and complexity journalistic work inside newsrooms tend to be both more routinised and differentiated, or even de-skilled, relying less on individual judgements and more on organisational procedure. These basic facts of life are reflected in the attitudes of journalists. Their loyalty goes rather to their media than to an abstract common ideology.

Some authors expect occupations to develop towards a stage of professionalism in similar stages, to unfold as it were a "natural history". History does not confirm many of the prescribed early stages of professionalisation outside the AngloAmerican world. ${ }^{82}$ Neither do we believe that a state of professional maturity can be secured once and forever. Professions are subject to varying external pressures and may temporarily loose control.

Theories of professionalisation are too individualistically oriented to be applicable to a culturally sensitive and organisationally anchored occupation like journalism. European journalism was only to some extent a copy of the American «original». We do not think that the profession of journalism develops independent of the various social and political systems to which it belongs. However, in many countries journalism has acquired similar elements of professionalism over time, as anticipated by sociological theories, but not in the succession prescribed.

Our own strategy towards a more realistic answer to the issue of journalistic professionalism has first been to admit the deficiencies in journalism as measured by classical theories and ideals. By sort of a counter-attack we have pointed out the inadequacies of such theories not only for journalism, but also increasingly for the most typical working environments of classical professions. As we have just pointed out both traditional and new professions are increasingly organised in teams and bound to large organisations, like the journalists have been for long.

\section{Notes}

1. The proportion of authors of fiction, mentioned in the histories of Norwegian literature, who were also active in the press as editors, publishers, regular writers or contributors to newspapers fell from $94 \%$ of registered authors for the period 1814-49 to $69 \%$ for the period $1870-88$. See: Svennik Høyer and Øyvind Ihlen (1995). "Forfattere i pressen." (Authors in the press. On the relationship between writers and the press in the nineteenth century.) Norsk medietidsskrift. Vol. 2, no. 1. See also Høyer, Svennik (2003) "Aviser uten journalister." (Newspapers without Journalists) in Ottosen, Rune og Roksvold, Thore (2003). Presseetikk. Festskrift for Odd Raaum. Krisitansand, Høyskoleforlaget.

2. The first advertising agencies came in the $1840 \mathrm{~s}$ in the US. The total input of advertising in the US press was approximately 11 million advertisements distributed over 2-3000 newspapers in 1847, increasing to 350 million advertisements distributed

over 16000 newspapers in 1897. A trade journal for the advertising industry was established in 1888 . See Alfred McClung Lee (1947). The Daily Newspaper in America. The Evolution of a Social Instrument. New York, Macmillan, and James R. Beninger (1986). The Control Revolution. Technological and Economic Origins of the Information Society. Cambridge, Mass., Harvard University Press.

3. We have greatly benefited from Ulf Jonas Björks remarks here. The professional style in America is much more individualistic than in Europe. We will return later to this difference, which helps to enlighten some differences in the origins of professional associations in general. A tradition of censorship in Europe seems to call for more collective efforts in the defense both of human rights, of press freedom as well as of other professional privileges.

4. The histories of organizations of the American journalists are quite contradictory. Publishers strongly opposed trade unions and thus apparently delayed

We want to thank The Norwegian Foundation for Applied Media Research and The Committee for the Nordic Social Science Research Councils and the Department of Media and Communication, University of Oslo and the Department of Journalism and Communication, University of Tartu for generous support for research and travels. 
their formation. See Arthur J. Kaul (1986). "The Proletarian Journalist: A Critique of Professionalism." Journal of Mass Media Ethics. Vol 1, no. 2 .

5. Dicken-Garcia (1989) finds in her comprehensive review of the public debate of journalistic standards in the 19th century America, that the word ethics appears in her material for the first time in 1889. See Hazel Dicken-Garcia (1989). Journalistic Standards in Nineteenth-Century America. Madison, University of Wisconsin Press. A French code of ethics for journalists dates back to 1918, a Swedish to 1923 , a Finnish to 1924 and a Norwegian to 1936. In most cases in a survey of 28 European countries, however, codes were adopted from the early 1950s and later. See Tiina Laitila (1995). "The Journalistic Codes of Ethics in Europe. A Report for the WAPC Conference in Helsinki, June 1st 1995." Department of Journalism and Mass Communication, University of Tampere. The first international codes of ethics were adopted in the 1930s.

6. Banning, Stephen A. (2000). "The Cradle of professional Journalistic Education in the Mid-Nineteenth Century." Media History Monographs. An online journal of Media History. Vol. 4, no 1 (http:/ /www.scripps.ohio.edu/media_history/mhanind. htlm)

7. Koszyk, Kurt (1966). Deutsche Presse im 19. Jahrhundert. Geschichte der deutschen Presse. Teil II. Berlin, Colloquium Verlag.

8. Himanen, Hannu (1985) Oppituolin historiasta. 60 vuotta toimittajakoulutusta. (Sixty years of journalism education in Finland.) Tampereen yliopiston tiedotusopin laitos. Tampere, Department of Communication, University of Tampere. Publications, series C, no. 7.

9. Björk, Ulf Jonas (1991). "The First International Organization of Journalists and the Issue of Professionalization". Paper for the American Journalism Historians Association in Philadelphia 1991. The French name of the ICP organization was Congrès international de la Presse. See also: Ulf Jonas Björk (1994: 193-205). "The Press Congress of the World and international standards for journalists 1921-26." Gazette Vol. 53.

10. “... the conduct of our journals falls too much into the hands of men of obscure birth, imperfect education, blunt feelings and coarse manners, who are accustomed to a low position in society, and are contented to be excluded from a circle in which they have never been used to move." Taken from the London Review for 1835 allegedly authored by Henry Brouggham and John Roebuck and quoted by Alan J. Lee (1976: 105) in his The Origins of the Popular Press in England 1855-1914. London, Croom Helm.

11. Harris, Michael (1983). "Journalism as a Profession or Trade in the Eighteenth Century." in Robin Myers, Michael Harris ET. Al. (1983) Author/Pub- lisher Relations During the Eighteenth and Nineteenth Centuries. Oxford, Oxford Polytechnic Press.

12. The relationship between increasing advertising in the press and decreasing partisanship has for long been a staple contention in the historiography of the American press, since Frank Luther Mott published his American Journalism; a History: 16901940 in 1941. Gerald Baldasty (1992) in his The Commercialization of News in the Nineteenth Century (Madison, University of Wisconsin Press) concludes that also the amount of political news decreased as a result of commercialisation in this period. See also Jeffery B Rutenbeck (1995: 361375). "Newspaper trends in the 1870s: Proliferation, Popularization, and Political Independence." Journalism \& Mass Communication Quarterly. Vol. 72. No. 2. The causal link between changing technology and changes in journalism, however, is strongly challenged by Michael Schudson (1997) in "Toward a Troubleshooting Manual for Journalism History". Journalism \& Mass Communication Quarterly. Vol. 74 / no. 3. Schudson demonstrate the opposite of Baldasty, namely that in amount of column space, political reporting increased in the period.

13. Both this and the following quote is taken from Allan J. Lee (1976: 104) op. cit. note 9; who in turn has taken them in from J. A. Spender (1925: 116). The Public Life, and from Kennedy Jones (1919), From Fleet Street to Downing Street.

14. James Curran gives the following progression of start-up investments for newspapers in London: in 1855 approx. $£ 20000$, in $1867 £ 50000$, in the $1870 \mathrm{~s} £ 150000$, in 1906-8£ 300000 and in the 1920s $£ 750$ 000. James Curran (1985: 38) "Press history" in James Curran and Jean Seaton (1985) Power without Responsibility. The Press and Broadcasting in Britain. London, Methuen. Collecting data from different sources William S. Solomon (1995) concludes similarly for New York: that in the space of some fifty-five years, [from 1841 to 1894 ] start-up costs had risen from a few thousands dollars to $\$ 1$ million. William S. Solomon (1995). "The Site of Newsroom Labor" in Hanno Hardt and Bonnie Brennen (1995). Newsworkers. Toward a History of the Rank and File. Minneapolis, University of Minnesota Press.

15. Ingersoll, Lurton D. (1873: 480). The Life of Horace Greeley. Chicago, Union Publishing.

16. Boyce, George (1978). "The Fourth Estate: the reappraisal of a concept." In George Boyce, James Curran And Pauline Wingate (1978). Newspaper history: from the 17th century to the present day. London, Constable. See also Jürgen Habermas (1989) The Structural Transformation of the Public Sphere. Cambridge, Mass., The MIT Press.

17. Tommila, Päiviö (1988). Yhdesta lehdesta sanomalehdistoksi 1809-1859. (From one news- 
paper to a Press 1809-1859.) Suomen lehdistön historia I. (The History of the Finnish Press.) Vol. I. Kuopio, Kustannuskiila.

18. Koszyk, Kurt (1966). Deutsche Presse im 19. Jahrhundert. Geschichte der deutschen Presse. Teil II. Berlin, Colloquium Verlag.

19. Brown, Lucy (1985:127-169) Victorian News and Newspapers. Oxford, Claredon Press.

20. Alan J. Lee (1976: 104-110) in his The Origins of the Popular Press in England 1855-1914. London, Croom Helm.

21. Taylor, S. J. (1996: 40). The Great Outsiders. Northcliffe, Rothermere and the Daily Mail. London, Weinfeld \& Nicolson.

22. Kaul, Arthur J. (1986: 47-55). "The Proletarian Journalist: A Critique of Professionalism." Journal of Mass Media Ethics. Vol. 1, no. 2.

23. Smythe, Curtis (1992). "The Reporter, 1880-1900: Working Conditions and Their Influence on the News." in Jean Folkerts (ed.) Media Voices. An Historical Perspective. New York, Macmillan.

24. "The perception that journalists have a low social standing and need organizations to raise their status permeates statements by European journalists in my research, but it is absent in American discussions", writes Ulf Jonas Björk in a comment to an earlier draft of this article.

25. Cronin, Mary M. (1993). "Trade Press Roles in Promoting Journalistic Professionalism 18841917." Journal of Mass Media Ethics. Vol 8, no. 4. Hanno Hardt and Bonnie Brennen, (eds.) 1995. Newsworkers. Toward a History of the Rank and File. Minneapolis, University of Minnesota Press. Hanno Hardt (1996) "The End of Journalism. Media and Newswork in the United States." Javnost - The Public; Vol. 3. no.3.

26. Schudson, Michael (1978). Discovering the News. A Social History of American Newspapers. New York, Basic Books. Michael Schudson (1990). Origins of the Ideal of Objectivity in the Professions. Studies in the History of American Journalism and American Law. New York, Garland. For a critical note to Schudson, see Arthur J. Kaul (1986) op cit. note 23 .

27. Dicken-Garcia, Hazel (1989: 230). Journalistic Standards in Nineteenth-Century America. Madison, University of Wisconsin Press.

28. Schudson, Michael (1994). "Question authority: a history of the news interview in American journalism, 1860s-1930s." Media, Culture \& Society. Vol 16, no. 4.

29. Flegel, Ruth C. \& Steven H Chaffe (1971). "Influences of Editors, Readers and Personal Opinions on Reporters." Journalism Quarterly. Vol. 48, No 4, pp. 645-651.

30. Barnhurst, Kevin G. and John Nerone (2001) The Form of News. A History. New York, The Guilford Press.

31. Lee, Alan J. (1976: 120). Op. cit. note 10. Christopher Silvester (1993: 7) (ed.) writes in his intro- duction to The Penguin Book of Interviews. (London, Penguin), that W. T. Stead was responsible for popularizing the interview formulae in Britain in the 1880 s.

32. Quoted from Silvester, Christopher (ed.) (1993: 2). The Penguin Book of Interviews. An Anthology from 1859 to The Present Day. London, Penguin Books.

33. Wilke, Jürgen 1984 "The changing world of media reality." Gazette, Vol. 39, no. 3

34. Frus, Phyllis (1994) The Politics and Poetics of Journalistic Narrative. The Timely and the Timeless. Cambridge. Cambridge University Press.

35 . The phenomenon received attention in recent discussions about the character of journalistic performance. See: Hallin, D. (1992). "The Passing of the 'High Modernism' of American Journalism." Journal of Communication, Vol. 42, no. 3.

36. Schiller, Dan (1979: 46-57). "An Historical Approach to Objectivity and Professionalism in American News Reporting." Journal of Communication, Vol. 29, autumn. Frank Luther Mott (1942). American Journalism. A History of Newspapers in the United States Through 250 Years. New York, Macmillan.

37. Dicken-Garzia, Hazel (1989: 143). Journalistic Standards in Nineteenth-Century America. Madison, University of Wisconsin Press.

38. Kaplan, Richard (1997). "The American Press and Political Community: Reporting in Detroit 18651920. Media Culture \& Society. No 1.

39. Ralph, Julian (1903: 184). The Making of a Journalist. London and New York, Harper and Brothers.

40. Schudson, Michael (1978: 144). Discovering the News. A Social History of American Newspapers. New York, Basic Books.

41. Nerone, John C. (1987: 401). "The Mythology of the Penny Press." Critical Studies in Mass Communication. Vol 4: 376-404.

42. Boyce, George (1978). "The Fourth Estate: the reappraisal of a concept." In George Boyce, James Curran And Pauline Wingate (1978). Newspaper history: from the 17th century to the present day. London, Constable.

43. Owen V. Johnson (1999: 8-10). "The roots of journalism in Central and Eastern Europe". In Jerome Aumente Et. Al. (eds.) Eastern European Journalism. Before, During and After Communism. Cresskill N.J., Hampton Press.

44. Chalaby, Jean K. (1996). "Journalism as an AngloAmerican Invention. A Comparison of the Development of French and Anglo-American Journalism, 1830s-1920s." European Journal of Communication. Vol. 11 (3): 303-326. Chalaby Jean K. (1998). The Invention of Journalism. Basingstoke: Macmillan.

45. Such techniques of 'double talk', as termed by George Orwell, writing between lines and allegorically alluding to actual events, hinted at but not mentioned in the text, were also highly developed 
during Soviet time in Eastern Europe. For a manifestation of latent public opinion during the transition from Communist rule in Hungary see: Róbert Angelusz (1992). "From Latency to Manifestation. On the Nature of Latent Public Opinion." in Svennik Høyer, Bjarne Skov and Line Sandsmark (eds.) (1992). The Role of Media in Changing Society. Papers from the Baltic-Norwegian Conference, October 1991. Oslo, Department of Media and Communication. (Report no. 6). See also Epp Lauk (1999) "Practice of Soviet Censorship in th Press. The Case of Estonia". Nordicom-Information. Vol. 21 nr. 3.

46. Donsbach, Wolfgang and Bettina Klett (1993: 5657). "Subjective objectivity. How journalists in four countries define a key term of their profession." Gazette. Vol 51

47. For Scandinavia see Niels Thomsen (1972) Dagbladkonkurrencen 1870 - 1970. (Newspaper Competition 1870-1970). København, Gads. Svennik Høyer (1995) Pressen mellom teknologi og samfunn. (The Press Between Technology and Society.) Oslo, Universitetsforlaget. For the United States see Alfred M. Lee (1937) The Daily Newspaper in America. New York, Macmillan; and Frank Luther Mott (1942) American Journalism. New York, Macmillan.. For a diffusion curve of newspaper circulation, see Melvin DeFleur (1970). Theories of Mass Communication. 2nd edition. New York, David McKay.

48. Printing capacity was probably less decisive for the increased newspaper consumption in Scandinavia in the closing decades of the 19th century - when newspapers in general had modest circulation figures - compared to the sharply falling prices on newsprint, which brought cheaper subscription, and copy prices. See: Svennik Høyer op. cit., note 1.

49. Lauk, Epp. (1990). On the Development of Estonian Journalism from 1900 to 1914. Acta Universitatis Stockholmiensis. Studia Baltica Stockholmiensia 5, 539-554.

50. Thomsen, Niels (1972: 253-259) Dagbladkonkurrencen 1870 - 1970. (Newspaper Competition 1870-1970). København, Gads.

51. Marzolf, Marion (1982). "Pioneers of «New Journalism» in early 20th Century Scandinavia." Pressens Arbog Vol. 20. This diffusion of journalistic forms has been speeded up in the age of global television. TV-news for example is not identical but in many respects very similar the world over in presentation, graphics and in its 30 minutes, 10-15 stories long formats. $\mathrm{CNN}$ being one of the few exceptions.

52. Elliot, Philip (1972). The Sociology of the Professions. London, Macmillan. Richard, H. Hall. (1968: 92-104) "Professionalization and Bureaucratization". American Sociological Review. Vol. 33, No 103. Keith M. MacDonald (1995). The Sociology of the Professions. London, Sage. Geoffrey Millerson (1964 a). The Qualifying As- sociations. A Study in Professionalization. London, Routledge \& Kegan Paul. Geoffrey Millerson (1964 b) "Dilemmas of Professionalism". New Society. No 4, June 1964. Terence J. Johnson (1979). Professions and Power. London, Macmillan. Harold L. Wilensky (1964: 137-158) "The Professionalization of Everyone?" The American Journal of Sociology. Vol. LVV, No. 2.

53. Daheim, Hansjürgen (1967). Der Beruf in der moderner Gesellschaft. Versuch einer soziologischen Theorie des beruflichen Handels. Köln, Hans Albrecht Hesse (1972) Berufe im Wandel. Stuttgart, (2. überarbeitete Auflage). Sven Windahl (1975). Professionella kommunikatörer. (Professional Communicators) Lund, Studentlitteratur. Svennik Høyer and Pål M. Lorentzen (1977: 95115). "The Politics of Professionalization in Scandinavian Journalism" in Mie Berg et. al. (eds.) (1977). Current Theories in Scandinavian Mass Communication Research. Århus, GMT. Lars Furhoff (1974). Makten över medierna. (Power Over the Media). Lund, Studentlitteratur. Pertti Hemánus (1979). Journalismista ja sen kehityspiirteistä. (On Journalism and Traits of its Development.) SSLH Julkaisuja. No 13. Helsinki. Tuomo Korteniemi (1987). Professionalistinen toimittaja. Tutkimus professionalismin käsitteen soveltamisesta toimittajan ammattiin. (The Professional Journalist: Applying the Term 'Professionalism' on the Journalistic Occupation.) Sosiologian pro gradu tutkielma. Helsinki University.

54. Millerson, Geoffrey. (1964 b: 10) The Qualifying Associations. A Study in Professionalization. London, Routledge 1964.

55. The Finnish sociologist Esa Konttinen (1989) has made a detailed survey on the development of theories of professionalism in his: Harmonian takuumiehia vai etuoikeuksien monopolisteja? Professioiden sosiologian funktionaistisen ja uusweberiläisen valtasuuntauksen tarkastelua. (Guarantees of Social Harmony or Monopolies of Privileges? Functionalist and Neo-Weberian approaches in the sociology of professions). Jyväskylä: Jyväskylän yliopiston sosiologian laitoksen julkaisuja/Publications of the Department of Sociology of the University of Jyväskylä. 45.

56. Johnson., Terence J. (1972; 1981). Professions and Power. London Macmillan. Pp. 24-25.

57. O'Boyle, Leonore (1968). "The Image of the Journalist in France, Germany and England 1815-1848." Comparative Studies in Society and History. Vol. X, 1968, pp. 290-317. See also: Hans Matthias Kepplinger and Renate Köcher (1990). "Professionalism in the Media World?" European Journal of Communication. Vol. 5, No 2-3 , pp. 285-311.

58. Wilensky, Harold L.(1964). "The Professionalization of Everyone?" The American Journal of Sociology. Vol LVV, no. 2. pp. 142-146.

59. Siegrist, Hannes (1990). "Professionalization as a process: patterns, progression and discontinuity." 
In Michael Burrage and Rolf Torstendahl (eds) (1990). Profession in Theory and History. Rethinking the Study of the Professions. London, Sage.

60. Corfield, Penelope J. (1995). Power and the Professions in Britain 1700 - 1850. London, Routledge.

61. Beam, Randal A. (1990). Journalism Professionalism as an Organizational Level Concept. Journalism Monographs, no. 121, June 1990.

62. Christian, Harry (1980: 259-301). “Journalist's occupational ideologies and press commercialization." in Harry Christian (et. al. eds.) (1980) The Sociology of Journalism and the Press. Univ. of Keele. Philip Elliott (1978: 172-191). "Professional ideology and organizational change: the journalist since 1800." in George Boyce, James Curran, Pauline Wingate (eds) (1978). Newspaper History from the 17th Century to the Present Day. London, Constable. See also: Edward J. Gerald (1964) The Social Responsibility of the Press.. Minneapolis, The Univ. of Minnesota Press. Minneapolis.

63. Sparks, Colin and Slavko Splichal (1994). Journalists for the 21st Century. Tendencies of Professionalization Among First-Year Students in 22 Countries. Norwood N.J: Ablex.

64. Weaver, David H. (1998). The Global Journalist. News People Around the World. Creskill N.J., Hampton Press

65. Esaiasson, Peter and Tom Moring (1994). "Codes of Professionalism: Journalists versus Politicians in Finland and Sweden." European Journal of Communication. Vol. 9 / 1994. pp. 271-289.

66. Köcher, Renate (1986). "Bloodhounds or Missionaries: Role Definitions of German and British Journalists" in European Journal of Communication. Vol 1 no. 1 / 1986.

67. Tepljuk, V. M. (1989: 109-23). "The Soviet Union: Professional Responsibility in Mass Media." in T. W. Cooper, C.G. Christians, F. F. Plude and R. A. White (eds.) (1989). Communication Ethics and Global Change. New York, Longman.

68. Vihalemm, Peeter, Lauk, Epp, Lauristin Marju (1997). "Estonian Media in the Process of Change". Return to the Western World. Cultural and Political Perspectives on the Estonian Post-Communist Transition. Ed. by Marju Lauristin \& Peeter Vihalemm with Karl Erik Rosengren \& Lennart Weibull. Tartu: Tartu University Press, 227-240); Sparks, Colin (2000). «Media theory after the fall of European communism. Why the old models from East and West won't any more.» De-Westernizing Media Studies. Ed. by James Curran \& Myung-Jin Park. Routledge: London and New York, pp. 35-49.

69. Lauk, Epp (1996). "Estonian Journalists in Search of New Professional Identity". Javnost. The Public. Vol. 3, no. 4

70. Nordenstreng, Kaarle (2003). "Media Ethics in Europe: In Search of Core Values." In Ottosen, Rune og Roksvold, Thore (eds.) Presseetisk front.
(The Frontier of Press Ethics). Kristiansand, IJforlaget.

71. Weaver, David H. and Wilhoit, G. Cleveland (1986) The American Journalist. A Portrait of U.S. News People and Their Work. Bloomington, Indiana University Press. Weaver, David H., and Wilhoit, G. Cleveland (1996). The American Journalist in the 1990s. U.S. News People at the End of an Era. Mahwah N.J., Lawrence Erlbaum.

72. Weaver, David H. and G. Cleveland Wilhoit (1996). The American Journalist in the 1990s. Mahwah N.J., Lawrence Erlbaum.

73. Helle, Merja (2000: 81-114). "Disturbances and contradictions as tools for understanding work in the newsroom." Scandinavian Journal of Information Systems. Vol. 12.

74. Johnstone, John W.C. (1976: 5-13). "Organizational Constraints on Newswork". Journalism Quarterly. Vol. 53, No 1. Philip Elliott (1977: 142173). "Media Organizations and Occupations: an Overview." in James Curran, Michael Gurevitch, Janet Woolacott (eds.) (1977) Mass Communication and Society. See also: Jeremy Tunstall (1977). «Editorial sovereignty" in the British Press." in Oliver Boyd-Barret et. al. (1977). Studies on the Press. Royal Commission on the Press. Working paper no. 2. London, Her Majesty's Stationary Office. Palmela J. Shoemaker (1991). Gatekeeping. Newsbury Park, Sage.

75. Johnstone, John W. C., Edward J. Slawski and William W. Bowman (1976) The News People. A Sociological Portrait of American Journalists and Their Work. Urbana, University of Illinois Press

76. Høyer, Svennik (1996). "Can «objectivity» save the autonomy of journalism? Some critical remarks." Javnost. The Public. Vol. 3, no. 3.

77. Sahlin-Andersson, Kerstin (1995). Cheföverläkarens ledarskap i en profesjonell, politisk och ekonomisk styrd verksamhet. (The leadership of chief physicians in a professional, political and economically controlled organization.) Stockholm, Landstingsförbundet.

78. Gjerløw Aasland, Olav (1997: 920). «Eliteleger og grasrotleger - en økende konflikt?» (Elite physicians and the rank and file doctor - an escalating conflict?). Tidsskrift for Den norske lageforening 7/1997 (The Journal of the Norwegian Medical Association). The same classification may profitably be used in studies of journalists.

79. Fugelli, Per, Grete Stang og Bente Wilmar (eds.) (2003) Makt og medisin. (Power and Medicine). Oslo, Rapportserien / Makt og demokratiutredningen 1998-2003, nr. 57

80. Allen, David S (2001) "The First Amendment and the doctrine of corporate personhood" Journalism,vol.2, no. 3 (255-78).

81. Perkin, Harold (1989) The Rise of Professional Society. England Since 1880. London, Routledge. 
82. An example of the study on the development of professions in Europe can be found in: Konttinen, Esa (ed.) (1993). Ammattikunnat, yhteiskunta ja valtio. Suomalaisten professioiden kehityskuvia. (Professions, Society and State. On the Develop- ment of the Professions in Finland). Jyväskylän yliopiston sosiologian laitoksen julkaisuja/ Publications of the Department of Sociology of the University of Jyväskylä. 55 . 